Vol. 1 No. 2 September 2021, p-2797-5592 | e-2797-5606

\title{
PENINGKATAN KOMPETENSI GURU DALAM PEMBELAJARAN DARING MELALUI LOKAKARYA PEMBUATAN BAHAN AJAR BERBASIS PLATFORM GOOGLE FOR EDUCATION DI SMP NEGERI 2 TARAKAN
}

\author{
JAHRAH \\ SMP Negeri 2 TARAKAN \\ e-mail: jahrah.tharif.soib@gmail.com
}

\begin{abstract}
ABSTRAK
Pada pembelajaran daring semua elemen pedidikan dituntut untuk tetap memfasilitasi pembelajaran agar tetap aktif meskipun tanpa tatap muka secara langsung. Sehubungan dengan adanya kegiatan belajar dari rumah atau disebut dengan BDR di SMP Negeri 2 Tarakan , maka guru diharapkan bisa menyampaikan materi pembelajaran atau kegiatan pembelajaran secara daring dengan menggunakan teknologi baik melalui WAG, google meet, zoom atau google classroom. Awalnya disekolah kami banyak guru merasa kesulitan untuk melakukan proses pembelajaran secara daring karena kemampuan guru dalam bidang teknologi khususnya menggunakan aplikasi-aplikasi pembelajaran sangat kurang, guru-guru di SMP Negeri 2 Tarakan juga merasa sangat bingung bagaimana menyampaikan materi pelajaran, tugas-tugas untuk peserta didik dengan baik dan dapat dipahami oleh peserta didik. kurangnya kemampuan/kompetensi guru-guru di SMP Negeri 2 Tarakan dalam bidang IPTEK menggunakan aplikasi-aplikasi pembelajaran maka Kepala Sekolah dan Tim Managemen sekolah memandang perlu diadakannya lokakarya yang dapat meningkatkan kompetensi guru dalam bidang IPTEK khususnya menggunakan aplikasi-aplikasi pembelajaran sehingga guru dapat merencanakan, melaksanakan dan mengevaluasi kegiatan pembelajaran secara daring dengan baik, disamping itu melalui lokakarya ini diharapkan guru-guru dapat sharing dan berbagi pengetahuannya dalam bidang IPTEK. Metodelogi yang digunakan dalam penelitian ini adalah deskriptif kualitatif dengan instrumen berupa wawancara kepada panitia penyelenggara lokakarya dan kuesioner yang diberikan kepada guru-guru SMP Negeri 2 Tarakan pada bulan Oktober 2021. Hasil penelitian menunjukan adanya antusias guru-guru SMP Negeri 2 Tarakan untuk mengikuti lokakarya yang dilaksanakan oleh panitia dan terjadi peningkatan kompetensi guru setelah mengikuti lokakarya pembuatan bahan ajar berbasis platform google for education.
\end{abstract}

Kata kunci : Kompetensi Guru, Pembelajaran Daring, Lokakarya Pembuatan Bahan Ajar

\section{PENDAHULUAN}

Berbagai kebijakan dan pemberlakuan protokol kesehatan dilakukan untuk memutus mata rantai penyebaran covid19. Lockdown di negara-negara yang terdampak covid-19 berimbas pada dunia kerja yaitu WFH (Work from Home) bahkan merumahkan para pegawainya. Di dunia pendidikan, kebijakan SFH atau School from Home pun diterapkan untuk menekan penularan covid-19. Sekolah-sekolah ditutup dan pembelajaran daring-pun dilakukan. (Jajat Sudrajat, 2020)

Pada pembelajaran daring ini semua elemen pendidikan dituntut untuk tetap menfasilitasi pembelajaran agar tetap aktif meskipun tanpa tatap muka secara langsung. Disini Guru selaku elemen utama dalam pendidikan formal memiliki peranan penting dan dipacu untuk melakukan adaptasi dengan pelaksanaan pembelajaran yang semula menggunakan metode tatap muka konvensional dan beralih ke pembelajaran daring (Setyorini, 2020). Kementerian Pendidikan dan Kebudayaan (Kemendikbud) menerbitkan Surat Edaran Nomor 15 Tahun 2020 tentang Pedoman Penyelenggaraan Belajar dari Rumah dalam Masa Darurat Penyebaran COVID-19. Tujuan pelaksanaan Belajar Dari Rumah (BDR) adalah untuk memastikan pemenuhan hak peserta didik untuk mendapatkan layanan Belajar dari Rumah (BDR) secara dalam jaringan (daring) dan luar jaringan (luring) memang menjadi tantangan bagi guru dalam penerapannya. Banyak pihak juga yang menyoroti praktik BDR yang dianggap 
masih memberatkan siswa. Oleh karena itu guru harus mampu mengembangkan kreativitas dan inovasi dalam pembelajaran. Para guru juga harus belajar lebih kreatif lagi agar siswanya tidak merasa bosan. Pembelajaran daring (online) dapat berjalan dengan baik, efektif dan menyenangkan diperlukan motivasi dalam kegiatan pembelajaran tersebut. Motivasi siswa penting karena motivasi merupakan salah satu faktor yang mempengaruhi keberhasilan dalam belajar. Jika para siswa termotivasi maka mereka akan belajar dengan sungguh-sungguh untuk mencapai tujuan pembelajaran (Emda,2017) Agar tujuan pembelajaran ini dapat terwujud, maka diperlukan peran guru secara profesional dalam kemampuan intelektual, pedagogik, kecerdasan emosional juga kreativitas yang dapat membantu berkembangnya proses pembelajaran yang diberikan. Metode pembelajaran yang kurang tepat dan tidak variatif merupakan masalah yang sering dihadapi para guru terutama dalam pembelajaran daring.

Sejalan dengan penelitian yang dilakukan oleh jajat Sudrajat (2020) yang berjudul Kompetensi Guru Di Masa pandemic Covid-19 mengatakan bahawa ditemukan bahwa kompetensi guru terkait kompetensi penguasaan literasi dan IPTEK, kompetensi keterampilan pengelolaan kelas dan kompetensi komunikasi dan sosial, belum optimal. Diperlukan pengembangan kompetensi-kompetensi tersebut sehingga akan meminimalisir masalah masalah yang ada dalam pembelajaran daring, sehingga proses belajar dapat berjalan lebih baik. Selain itu penelitian yang dilakukan oleh Intan Salafiah, dkk yang berjudul Kompetensi Guru Dalam Memanfaatkan Media Pembelajaran Berbasis Tekhnologi, Informasi dan komunikasi di SDN 16 Banda Aceh, guru sudah cukup baik dalam memanfaatkan media pembelajaran berbasis TIK, namun masih dibutuhkan banyak bimbingan dalam mengakses langsung media dari internet. Kedua, guru yang kurang mampu menggunakan TIK disebabkan oleh faktor usia. Ketiga, guru yang kurang mampu menggunakan TIK masih terikat dengan media konvensional yang ada di lingkungan sekitar. Simpulan penelitian ini yaitu kompetensi yang dimiliki oleh guru dalam memanfaatkan media pembelajaran berbasis TIK sudah cukup baik. Namun masih diperlukan banyak bimbingan dalam mencari media dan sumber belajar dari internet. Disarankan untuk pihak sekolah agar lebih meningkatkan lagi pengadaan bimbingan mengenai TIK bisa melalui pelatihan, seminar, bahkan lokakarya, sehingga beberapa kendala dalam pemanfaatan TIK sebagai media pembelajaran dapat diatasi.

Pada saat inilah, peranan guru sangat dibutuhkan. Guru di tuntut untuk memiliki kompetensi guna menunjang peserta didik pada masa pandemi ini,namun kompetensi sangat sulit dilakukan manakala pembelajaran daring diberlakukan karena akan ada banyak masalah yang terjadi dalam kondisi yang berubah salah satunya kurangnya pemahaman dari peserta didik dalam belajarnya (Sudrajat, 2020). Dalam hal ini, guru berperan mengawasi dan mengevaluasi peserta didik dan berupaya membuat pembelajaran lebih baik agar peserta didik tuntas dalam belajarnya.

Sehubungan dengan adanya kegiatan belajar dari rumah atau disebut dengan BDR di SMP Negeri 2 Tarakan, maka guru diharapkan bisa menyampaikan materi pembelajaran atau kegiatan pembelajaran secara daring dengan menggunakan teknologi baik melalui WAG, google meet, zoom atau google classroom. Awalnya disekolah kami banyak guru merasa kesulitan untuk melakukan proses pembelajaran secara daring karena kemampuan guru dalam bidang teknologi khususnya menggunakan aplikasi-aplikasi pembelajaran sangat kurang, guruguru di SMP Negeri 2 Tarakan juga merasa sangat bingung bagaimana menyampaikan materi pelajaran, tugas-tugas untuk peserta didik dengan baik dan dapat dipahami oleh peserta didik.

Dari sisi hasil pembelajarannya, siswa tentu tidak semudah menangkap pembelajaran secara langsung seperti manakala berada di sekolah. Diperlukan penguasaan alat pembelajaran, materi pembelajaran dan komunikasi yang baik dalam menyampaikan pembelajaran melalui daring. Kebijakan sekolah yang menerapkan pembelajaran daring untuk pelaksanaan kegiatan belajar mengajarnya, membutuhkan keterampilan dibidang IPTEK. Kurangnya penguasaan guru terhadap IPTEK akan mempengaruhi tingkat kelancaran kegiatan belajar mengajar melalui daring dan proses pembimbingan siswa jarak jauh.Untuk itu Guru-guru di SMP Negeri 2 Tarakan dipandang perlu memiliki kompetensi-kompetensi tertentu yang mendukung 
Vol. 1 No. 2 September 2021, p-2797-5592 | e-2797-5606

keberhasilan pembelajaran siswa pada masa pandemi ini. Tulisan ini akan membahas lebih lanjut kompetensi sumber daya manusia yang diperlukan, dalam hal ini guru sebagai pendidik, dalam tugas dan tanggung jawabnya menjalankan profesinya di tengah pandemi ini.

Dengan kurangnya kemampuan/kompetensi guru-guru di SMP Negeri 2 Tarakan dalam bidang IPTEK menggunakan aplikasi-aplikasi pembelajaran maka Kepala Sekolah dan Tim Managemen sekolah memandang perlu diadakannya lokakarya yang dapat meningkatkan kompetensi guru dalam bidang IPTEK khususnya menggunakan aplikasi-aplikasi pembelajaran sehingga guru dapat merencanakan, melaksanakan dan mengevaluasi kegiatan pembelajaran secara daring dengan baik, disamping itu melalui lokakarya ini diharapkan guru-guru dapat sharing dan berbagi pengetahuannya dalam bidang IPTEK.

\section{METODE PENELITIAN}

Penelitian ini merupakan jenis penelitian deskriptif kualitatif, disini peneliti mengumpulkan data-data dalam bentuk kata-kata/ narasi atau gambar-gambar dalam pemamfaatkan platform google for education dalam kegiatan pembelajaran secara daring pada saat pandemi covid-19. Penelitian ini dilaksanakan pada tanggal 26 -28 Juli 2021 di SMP Negeri 2 Tarakan, selama 3 hari yang diikuti oleh seluruh guru-guru baik PNS atau Non PNS dengan jumlah peserta lokakarya ada 41 orang guru terdiri atas 34 guru perempuan dan 7 guru laki-laki. Langkah-langkah metode kualitatif yang peneliti gunakan yaitu: 1. Melakukan wawancara secara langsung kepada panitia penyelenggara lokakarya dengan pertanyaan terbuka tentang latar belakang dipilihnya judul kegiatan lokakarya yaitu pembuatan bahan ajar berbasis platform google for education. Pertanyaan terbuka yang diberikan oleh peneliti berupa pertanyaan secara lisan dengan 5 buah pertanyaan 2. Melakukan observasi pada guru terkait platform pembelajaran yang digunakan pada saat pembelajaran jarak jauh sesudah mengikuti lokakarya pembuatan bahan ajar berbasis platform google for education 3. Dokumentasi guru saat mengikuti lokakarya dan foto guru saat menggunakan platform google for education.

\section{HASIL DAN PEMBAHASAN}

\section{Hasil}

1. Berdasarkan hasil wawancara secara langsung dengan lima buah pertanyaan terbuka kepada ketua panitia penyelenggara lokakarya pembuatan bahan ajar berbasis platform google for education di SMP Negeri 2 Tarakan yaitu:

- Latar belakang diselenggarakannya lokakarya adalah karena sebagian besar guru walaupun daring tapi menggunakan cara mengajar yang tradisonal yaitu meminta peserta didik mengantar tugas ke sekolah dan tugas yang diberikan lewat WA group

- Alasan memilih Lokakarya pembuatan bahan ajar berbasis platform for education adalah karena gratis, mudah dan paktis dalam menggunakan.

- Antusias guru dalam mengikuti pelaksanaan lokakarya adalah sangat antusias untuk belajar platform google for education apalagi sangat penting dalam pembelajaran secara daring pada masa pandemik covid-19 ini

- Narasumber yang diundang adalah narasumber yang sudah memiliki kualifikasi untuk google for education

- Alasan memilih narasumber tersebut karena narasumber memiliki kualifikasi dan kompetensi sesuai dengan materi yang akan dipelajari guru-guru SMP Negeri 2 Tarakan walaupun bukan berasal dari praktisi atau guru.

Melalui wawancara secara langsung kepada panitia tersebut maka peneliti membuat kesimpulan bahwa untuk meningkatkan kompetensi guru-guru dalam pembelajaran secara daring pada masa pandemik covid-19 ini yaitu dengan mengadakan lokakarya pembuatan bahan ajar berbasis google for education di SMP Negeri 2 Tarakan, diharapkan guru-guru mampu membuat bahan ajar dalam pembelajaran dengan mudah dan praktis serta gratis dengan menggunakan akun guru.belajar.id, disamping itu narasumber yang memberikan materi juga 
Vol. 1 No. 2 September 2021, p-2797-5592 | e-2797-5606

memiliki kualifikasi sertifikat google for education sehingga guru-guru peserta pelatihan sangat antusias untuk belajar.

\section{Hasil}

2. Berdasarkan hasil Observasi pada guru-guru sebagai peserta lokakarya terkait platform pembelajaran yang digunakan pada saat pembelajaran jarak jauh sesudah mengikuti lokakarya pembuatan bahan ajar berbasis platform google for education di SMP Negeri 2 Tarakan melalui kuesioner yang dibagikan kepada peserta lokakarya seperti ditunjukan pada tabel 1 dan grafik 1 berikut:

Tabel 1. Rekapitulasi Evaluasi kegiatan lokakarya penggunaan platform google for edukation

\begin{tabular}{llll}
\hline $\mathrm{N}$ & Aspek Yang Dinilai & $\begin{array}{l}\text { Jumla } \\
\mathrm{h}\end{array}$ & $\begin{array}{l}\text { Perse } \\
\mathrm{n}\end{array}$ \\
\hline 1 & Google Sheets & 8 & $23,5 \%$ \\
2 & Google Classroom & 33 & $97,1 \%$ \\
3 & Google formulir & 30 & $88,2 \%$ \\
4 & Google Slides & 6 & $17,6 \%$ \\
5 & Google Gambar & 4 & $11,8 \%$ \\
6 & Gmail & 14 & $41,2 \%$ \\
7 & Google Kalender & 2 & $5,9 \%$ \\
8 & Google Meet & 14 & $41,2 \%$ \\
9 & Chrome & 13 & $38,2 \%$ \\
10 & You Tube & 22 & $64,7 \%$ \\
11 & Google Maps & 1 & $2,9 \%$ \\
\hline
\end{tabular}

Evaluasi kegiatan lokakarya Pembuatan Bahan Ajar Berbasis Platfrom Google For Education yang dilaksanakan tanggal 26-28 Juli 2021 di SMP Negeri 2 Tarakan. Platform apa yang Bapak/lbu gunakan dalam mengajar atau Kegiatan Belajar Mengajar secara daring/online sampai sekarang (Boleh centang lebih dari satu)

34 jawaban

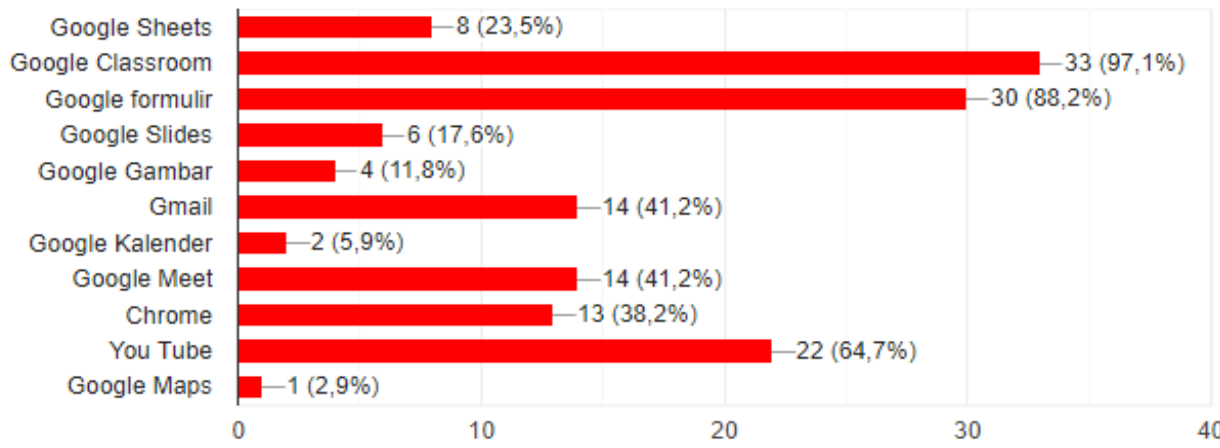

\section{Gambar 1. Grafik Rekapitulasi Evaluasi kegiatan lokakarya penggunaan platform google for edukation}

Berdasarkan tabel 1 dan grafik 1 tentang Rekapitulasi penggunaan platform google for education pada guru-guru SMP Negeri 2 Tarakan setelah mengikuti lokakarya, yaitu semua peserta lokakarya artinya dari 34 peserta pelatihan, $100 \%$ sudah semua menggunakan platform google for education pada saat melaksanakan pembelajaran jarak jauh atau daring walaupun tidak semua menggunakan platform yang ada pada google for education tersebut. Bapak/Ibu 
guru sebagai peserta pelatihan menggunakan platform google for education dalam proses mengajar aau kegiatan belajar mengajar secara daring/online sampai sekarang ini. Tiga Platform yang banyak digunakan guru-guru pada saat pembelajaran jarak jauh atau daring yaitu google classroom sebesar 33 peserta lokakarya atau sekitar $97,1 \%$, selanjutnya adalah google formulir 30 peserta lokakarya atau $88,2 \%$, dan yang ke tiga platform yang banyak digunakan adalah you tube sebesar 22 peserta lokakarya atau $64,7 \%$.

\section{Hasil}

3. Dokumentasi guru saat mengikuti lokakarya dan foto guru saat menggunakan platform google for education

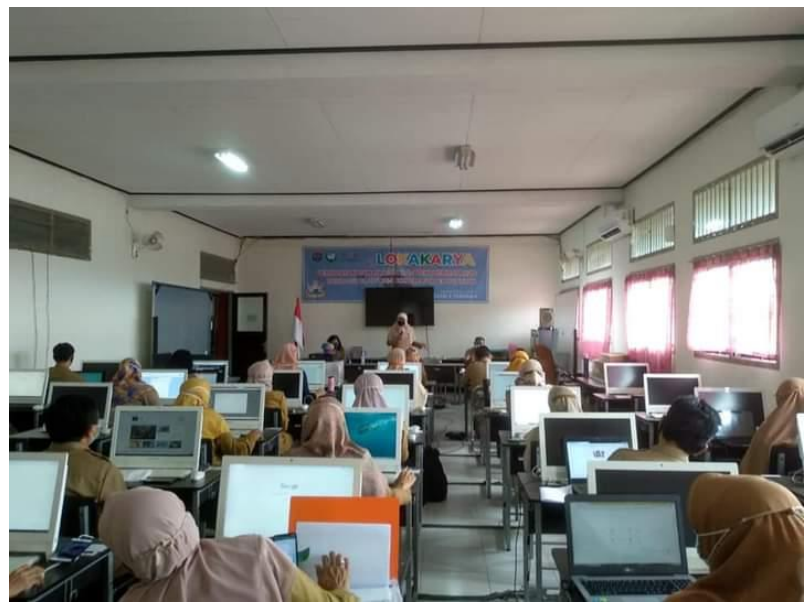

Gambar 1. Kegiatan saat pelaksanaan lokakarya pembuatan bahan ajar berbasis platform google for education di laboratorium komputer SMP Negeri 2 Tarakan

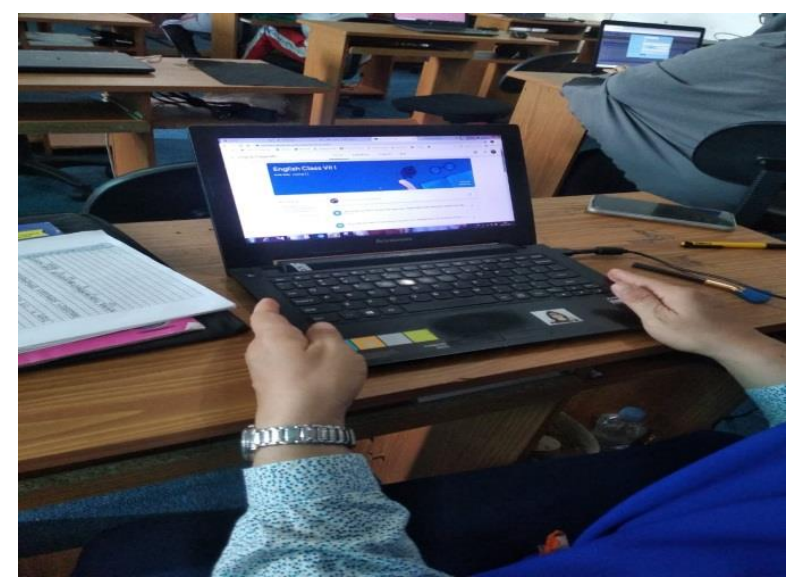

Gambar 2. Penggunaan platform google for education oleh guru peserta pelatihan dalam proses belajar mengajar di ruang laboratorium komputer SMP Negeri 2 Tarakan

\section{Pembahasan}

Berdasarkan gambar 1, tampak guru-guru SMP Negeri 2 Tarakan saat mengikuti lokakarya di laboratorium komputer terlihat sangat antusias mengikuti lokakarya pembuatan bahan ajar berbasis platform google for education, tampak narasumber menpaparkan dan memberikan arahan cara penggunaan platform google for education dan peserta lokakarya mempraktikannya didepan komputer atau laptop.

Dan pada gambar 2, terlihat dalam foto tersebut tampak guru menggunakan platfrom google for education yaitu menggunakan platform google classroom dalam kegiatan pembelajaran daring di SMP Negeri 2 Tarakan.

Dalam Peraturan Pemerintah (PP) RI No. 19 tahun 2005 tentang Badan Standar Nasional Pndidikan (BSNP) ditegaskan bahwa pendidik (guru) harus memiliki kompetensi sebagai agen pembelajaran pada jenjang pendidikan dasar dan menengah serta pendidikan anak 
Vol. 1 No. 2 September 2021, p-2797-5592 | e-2797-5606

usia dini. Arahan normatif itu menyatakan bahwa guru merupakan pihak pertama yang paling bertanggungjawab dalam pentransferan ilmu pengetahuan kepada peserta didik.

Terkait dengan pernyataan tersebut, mantan Menteri Pendidikan dan kebudayaan RI Fuad Hasan berpendapat bahwa, "sebaik apapun kurikulum jika tidak dibarengi oleh guru yang berkualitas, maka semuanya akan sia-sia. Sebaliknya kurikulum yang kurang baik akan dapat ditopang oleh guru yang berkualitas". Oleh sebab itu, peningkatan mutu guru sepatutnya menjadi perhatian utama dalam upaya dalam peningkatan mutu pendidikan.

Dari penyataan di atas menurut pendapat peneliti bahwa mutu pendidikan akan meningkat jika guru memiliki kompetensi yang berkualitas dan didukung oleh kurikulum yang baik sehingga ilmu pengetahuan dapat di transfer dengan baik kepada peserta didik. Hal ini diperkuat berdasarkan hasil penilitian atau teori (Mulyasa: 2020) "Peningkatan kompetensi guru melalui pendidikan dapat dilakukan melalui penataran, lokakarya atau seminar yang berkenaan dengan tugas utama guru di sekolah"

Teknologi dapat dimanfaatkan dalam kegiatan proses belajar mengajar, yang dapat dikatakan merupakan pergantian dari cara konvensional menjadi ke modern. (Gheytasi, Azizifar \& Gowhary (Khusniyah dan Hakim: 2019) "adanya teknologi memberikan banyak pengaruh positif terhadap pembelajaran". (Martins: 2015) "Internet digunakan untuk melengkapi aktivitas pembelajaran".

Pembelajaran daring merupakan sistem pembelajaran yang dilakukan dengan tidak bertatap muka langsung, tetapi menggunakan platform yang dapat membantu proses belajar mengajar yang dilakukan meskipun jarak jauh. Tujuan dari adanya pembelajaran daring ialah memberikan layanan pembelajaran bermutu dalam jaringan yang bersifat masif dan terbuka untuk menjangkau peminat ruang belajar agar lebih banyak dan lebih luas (Sofyana \& Abdul, 2019 hal $81-86$ )

Ada beberapa aplikasi juga dapat membantu kegiatan belajar mengajar, misalnya whatsapp, zoom, web blog, edmododan lain-lain. Pemerintah juga mengambil peran dalam menangani ketimpangan kegiatan belajar selama pandemi covid 19 ini. Melansir laman resmi Kemendikbud RI, ada 12 platform atau aplikasi yang bisa diakses pelajar untuk belajar dirumah yaitu (1) Rumah belajar; (2) Meja kita; (3) Icando; (4) Indonesiax; (5) Google for education; (6) Kelas pintar; (7) Microsoft office 365; (8) Quipper school (9) Ruang guru; (10) Sekolahmu; (11) Zenius; (12) Cisco webex

Berbagai platform yang tersedia untuk menunjang produktifitas dosen dalam pembelajaran. Google Classroom, Zoom, Google Meet, WA, Youtube, Quiziz, Mentimeter, dan lain sebagainya dapat digunakan oleh dosen dalam pembelajaran digital dengan menyesuaikan kondisi pada mahasiswa dan perubahan-perubahan atau kendala yang ditemui. Rosali (2020:26) "aplikasi utama yang sering digunakan adalah Youtube, Google Classroom, dan platform kuis yakni Quiziz".

Dikutip dari kompas.com, Sedikitnya ada 12 platform pembelajaran daring atau online yang siap diakses oleh siswa di seluruh Indonesia. Hal ini demi membantu siswa saat mengikuti pembelajaran jarak jauh terkait kebijakan pemerintah karena penyebaran virus corona. Karena itu, pemerintah melalui Kementerian Pendidikan dan Kebudayaan ( Kemendikbud) RI, bekerjasama berbagai platform yakni menyediakan aplikasi pembelajaran daring. Melansir laman resmi Kemendikbud RI, berikut ini ada 12 platform atau aplikasi yang bisa diakses siswa untuk belajar di rumah. Aplikasi ini sebagai bentuk bersama hadapi corona. Untuk mendukung belajar daring terutama yang di terapkan oleh berbagai daerah pada isu pandemi covid19, Google For Education menyediakan layanan menggunakan chromebooks dan G-Suite yang memungkinkan pembelajaran virtual walaupun dengan konektivitas internet yang rendah.

\section{KESIMPULAN}

Berdasarkan hasil penelitian ini didapatkan kesimpulan bahwa lokakarya ini diadakan karena kurangnya kemampuan/kompetensi guru-guru di SMP Negeri 2 Tarakan bidang IPTEK dalam menggunakan aplikasi-aplikasi pembelajaran, disamping itu guru melaksanakan 
Vol. 1 No. 2 September 2021, p-2797-5592 | e-2797-5606

pembelajaran secara tradisonal dengan meminta peserta didik mengumpulkan tugas ke sekolah, maka diadakan lokakarya pembuatan bahan ajar berbasis platform google for education yang disambut antusias oleh guru-guru SMP Negeri 2 Tarakan

Setelah mengikuti lokakarya terjadi peningkatan kompetensi guru dalam pembelajaran daring melalui lokakarya pembuatan bahan ajar berbasis platform google for education di SMP Negeri 2 Tarakan, hal ini dapat dilihat dari kemampuan guru-guru dalam menggunakan berbagai platform google for education dalam proses belajar mengajar secara daring dan menggunakan platform google for education tersebut sampai saat ini. Platform yang banyak digunakan adalah google classroom sebesar $97,1 \%$, dilanjutkan dengan google formulir sebesar $88,2 \%$ dan you tube sebesar $64,7 \%$ dan disusul dengan penggunaan platform-platform dalam google for education yang lain.

\section{DAFTAR PUSTAKA}

Depdiknas. (2006). Standar Kompetensi Guru Kelas SD/MI Lulusan S1 PGSD. Jakarta.

Emda, A. (2017). Kedudukan Motivasi Belajar Siswa dalam Pembelajaran. Lantanida Journal 5(2), 93-196

Kusniyah \& Hakim, L. (2019). Efektifitas Pembelajaran Berbasis Daring:Sebuah Bukti pada Pembelajaran Bahasa Inggris, Jurnal Pemikiran dan Penelitian Pendidikan, Vol. 17 No.1

Martins, M. de L. (2015). How to Effectively Integrate Technology in the Foreign Language Classroom for Learning and Collaboration. Procedia -Social and Behavioral Sciences. Vol.174,Halm.77-84

Mulyasa, H.E. (2020). Menjadi guru penggerak merdeka belajar/, H.E Mulyasa: editor, Lia narotut Darojah, -- Jakarta : bumi Aksara, 340 hlm ; $23 \mathrm{~cm}$

Mulyasa, E. (2007) Standar Kompetensi dan Sertifikasi Guru. Bandung. Rosdakarya

Rosali, S. E. (2020). 'Aktifitas Pembelajaran Daring Pada Masa Pandemi Covid-19 di Jurusan Pendidikan Geografi Uiversitas Siliwangi Tasilmalaya', Geosee, vol. 1 no. 1, hh. 21-30

Sofyana \& Abdul. (2019). Pembelajaran Daring Kombinasi Berbasis Whatsapp Pada Kelas Karyawan Prodi Teknik Informatika Universitas, PGRI Madiun. Jurnal Nasional Pendidikan Teknik Informatika. Volume 8 Nomor 1, Halm. 81-86

Sudrajat, Jajat. (2020). Kompetensi Guru Di Masa Pandemi Covid-19, Jurnal Riset Ekonomi Dan Bisnis, 13(1), 100-110. http://journals.usm.ac.id/index.php/jreb 